\title{
Kinetic Study of Gas Formation in Styrofoam Pyrolysis
}

\author{
I Dewe Ketut Anom \\ Chemistry FMIPA Manado State University. \\ Jl. Raya Tondano, Koya, Kab. Minahasa - Sulawesi Utara, Indonesia. \\ Email: dewaanom10@gmail.com
}

DOI: $\underline{10.29303 / a c a . v 4 i 1.76}$

Article info:

Received 01/10/2021

Revised 29/10/2021

Accepted 01/11/2021

Available online $03 / 11 / 2021$

\begin{abstract}
This research aims to study the reaction kinetics of gas formation in the pyrolysis of styrofoam waste. Pyrolysis of styrofoam waste without a catalyst takes place at a constant temperature of $180^{\circ} \mathrm{C}$. In contrast, the pyrolysis of styrofoam waste by adding a zeolite catalyst took place at a constant temperature of $170^{\circ} \mathrm{C}$. The amount of styrofoam waste used in this research sample is $200 \mathrm{grams}$, and the natural zeolite catalyst is 5 grams. Pyrolysis of styrofoam waste without using a catalyst form a gas at a constant temperature of $180^{\circ} \mathrm{C}$, the kinetics of the reaction takes place on the zero-order. This result follows the Arrhenius equation $K=A^{e 10617 / R T}$ with an activation energy value (Ea) of $1.27 \times 10^{3} \mathrm{~kJ}^{\mathrm{mol}}{ }^{-1}$. Pyrolysis of styrofoam waste by adding a zeolite catalyst to gas formation at a constant temperature of $170^{\circ} \mathrm{C}$ also takes place on the zero-order. The equation follows Arrhenius $K=A^{e 4711,5 / R T}$ and the activation energy value $(E a)$ is $5.66 \times 10^{2} \mathrm{~kJ}^{\mathrm{mol}}{ }^{-1}$.
\end{abstract}

Keywords: Styrofoam, Pyrolysis, Kinetics, Plastic Waste, Gas

Citation: Anom, I. D. K. (2021). Kinetic Study of Gas Formation in Styrofoam Pyrolysis, Acta Chimica Asiana, 4(2), 135-140. DOI: $\underline{10.29303 / a c a . v 4 i 1.76}$

\section{INTRODUCTION}

Styrofoam is a type of polystyrene (PS) plastic that is widely used in the community. This waste is used as food wrappers, as a buffer for electronic devices, and so on. Its light and soft nature is the reason why this material is practical for use in everyday life. The increasing population will increase the use of plastic-type goods [1], so the increase in waste is a consequence of the city's development [2]. The problem comes when styrofoam that has been used or is no longer used becomes garbage and is thrown away. As a type of plastic, styrofoam is included in the waste that cannot be decomposed quickly. All types of plastic take approximately 200 years to decompose naturally [3]. It can lead to the accumulation of plastic waste [4]. Solving the problem of plastic waste by burning is an incomprehensive action to take. The process of burning plastic will cause air pollution, where exhaust gases from combustion such as $\mathrm{CO}, \mathrm{CO} 2, \mathrm{NOx}$, and $\mathrm{SOx}$ will cause environmental problems [1]. The same thing is also explained by Bemis et al. (2012) that the burning of plastic waste can produce harmful gases such as carbon dioxide, sulfur oxides, and nitrogen oxides into the air [5]. The absence of an excellent plastic waste management solution will make one continue to dispose of or burn plastic waste. Westerhout et al. (1997) researched the pyrolysis kinetics of polyethylene and polypropylene plastic waste using the pyrolysis method at high temperatures [6]. Ethene, propene, butene, and styrene can be produced from this plastic waste which can then be used to produce polymers that can be sold for other purposes.

Styrofoam is composed of hydrocarbon compounds such as Styrene, Toluene, Isopropyl benzene, Benzene, and Xylen [7]. The presence of hydrocarbon in styrofoam provides an opportunity for reprocessing Styrofoam waste. It is because hydrocarbon compounds from plastic decomposition can be used to be processed into materials. According to Zurohaina et al. (2019), the calorific value of plastic is relatively high, equivalent to gasoline and heat [8]; thus, plastic decomposition can be an alternative solution to obtain renewable energy [9], besides that it can also be economically valuable 10]. Recycling of plastic waste which continues to increase has become an urgent global concern [11]. 
Styrofoam processing can be done by pyrolysis, which is a thermal decomposition technique with limited oxygen. The whole process will produce the main products of liquids, gases, and solids, residual heating. The pyrolysis technique is a solution for the decomposition of plastic waste. Apart from the easy way it works, pyrolysis will not produce new waste that can cause environmental problems [12]. Pyrolysis techniques must continue to be developed to obtain a good and efficient working procedure. Therefore it is necessary to study how the process of decomposition of substances during pyrolysis takes place. The decomposition process of substances in question is the chemical kinetics of substances, the relationship between time, temperature, the amount of product produced, and the effect of the addition of a catalyst on the pyrolysis process [13]. Kumara (2015) explained that in the pyrolysis process, a catalyst could be added to accelerate the decomposition reaction and shorten the hydrocarbon chain to condense into pyrolysis oil [14] efficiently. The presence of a catalyst can minimize the production of wax and heavy oil usually produced in the non-catalyzed pyrolysis process [15]. The presence of a catalyst can increase the yield of plastic pyrolysis results [16]. Pyrolysis is a decomposition reaction at high temperatures following a free radical reaction mechanism. The reaction goes through the initial stage, the decomposition stage, and the final stage or termination. In the early stages, the weak bond chains will be broken due to an increase in temperature. In the decomposition reaction stage, free radical reactions will be formed, accompanied by new, smaller, and more stable free radicals.

Research conducted by Feybi et al. (2021) on the pyrolysis of styrofoam plastic without a catalyst and added a catalyst in the formation of liquid smoke, the activation energy value $(\mathrm{Ea})$ is $17.554 \times 103 \mathrm{~kJ} / \mathrm{mol}$ in the uncatalyzed pyrolysis. The activation energy value (Ea) is $85.883 \times 103 \mathrm{~kJ} / \mathrm{mol}$ at pyrolysis added a catalyst, with the rate constant $(k)$

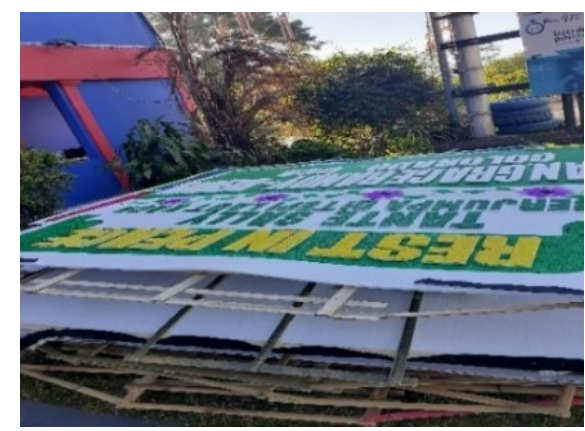

A

Figure 2. A. Examples of styrofoam; B. Zeolite according to the Arrhenius equation, where this research was carried out without controlling the temperature during pyrolysis [13]. In this study, it is also known that the catalyst affects the pyrolysis temperature. Based on the results of research that previous researchers have carried out, generally conducting research

\section{MATERIALS AND METHODS}

The tools used in this research are thermometer, round bottom flask, hotplate, condenser, water hose, liquid storage bottle, bent glass pipe, measuring cup, stative, and clamps. The research material or sample is styrofoam board waste that has been washed and dried in the sun. Styrofoam waste samples were cut into pieces with a size of $2-3 \mathrm{~cm}$. The catalyst used is natural zeolite. The materials used in this research are Styrofoam board and natural Zeolite catalyst. The series of Styrofoam waste pyrolysis equipment is designed as shown in Figure 1.

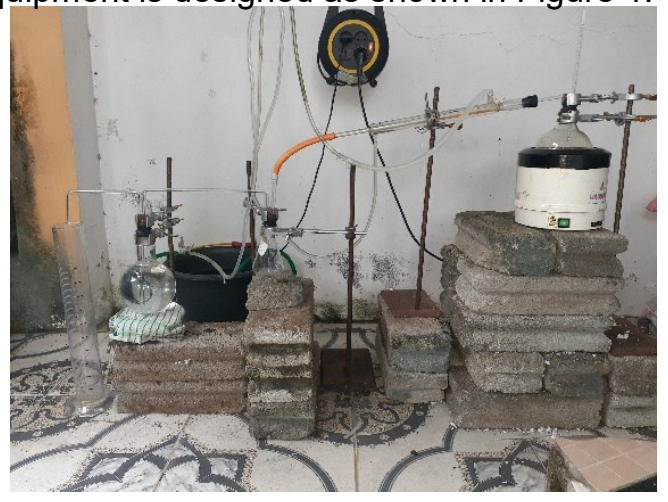

Figure 1. Pyrolysis equipment

Based on the series of tools designed, it can be seen that the pyrolysis process occurs in a minimal oxygen state or near a vacuum. However, according to Rosa et al. (2001), plastics' pyrolysis behavior under vacuum is generally comparable to that in a nitrogen atmosphere [17].

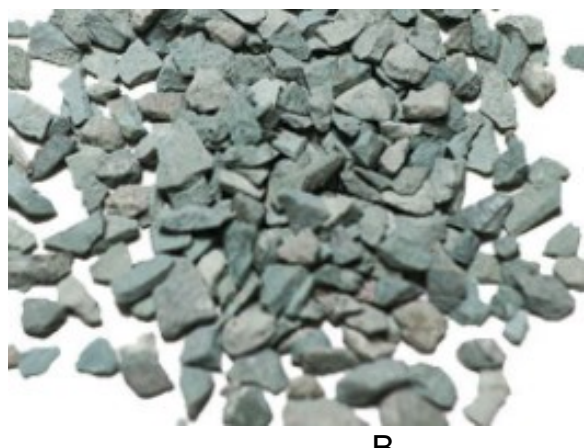

B 


\section{Procedure}

400 grams styrofoam were pulverized and then prepared into two containers weighing 200 grams each. 5 grams of Zeolite Catalyst was prepared by drying. The first pyrolysis was carried out without a catalyst, and the second pyrolysis was added with a catalyst. Observations of the product gas coming out were observed every 15-minute interval. Observation of gas is obtained by accommodating gas into a container that already contains water; thus, the amount of water that comes out represents the total volume of gas.

\section{RESULTS AND DISCUSSION}

\section{Pyrolysis Results}

The pyrolysis process of styrofoam waste without using a catalyst starts at a temperature of $100 \mathrm{oC}$. At this temperature, the styrofoam has begun to melt. At the same time, there is the gas that has been accommodated in the gas reservoir flask. The presence can see of water droplets dripping on the measuring cup holder. White smoke is formed at a temperature of around $1400 \mathrm{C}$, which resembles a fog that lasts approximately 30 minutes. At a temperature of $180 \mathrm{oC}$, the pyrolysis process of styrofoam waste takes place at a constant temperature. Observations of pyrolysis started at the 75th minute when the temperature was constant and ended at the 180th minute. The longer the pyrolysis time, the less gas volume per unit time formed. It was due to a decrease in the mass of styrofoam in the reactor. At the beginning of heating, the polymer, which has large molecules as constituents of styrofoam, decomposes quickly. The longer the heating, the slower the decomposition of the substance because the less the number of compounds contained can be decomposed. According to Naimah and Aidha (2017), the gas produced has hydrocarbon components that can be used as an energy source [18]. Pyrolysis of styrofoam waste without using a catalyst obtained a yield of $1020 \mathrm{~mL}$.

The second pyrolysis is the pyrolysis of 200 grams of Styrofoam waste by adding 5 grams of Zeolite catalyst. Heating starts at $130 \mathrm{oC}$, and at this temperature, the Styrofoam waste has started to melt. At a temperature of about $170 \mathrm{oC}$, healing begins to take place constantly. Observations started at the 105th minute at constant temperature and ended at the 210th minute. Pyrolysis of styrofoam waste using a catalyst obtained a yield of $1800 \mathrm{~mL}$. Naimah and Aidha (2017) explained that methane, propane, n-butane, and ethane gas were the main gases formed [18]. Methane gas is a gaseous fuel that is needed with the characteristics of being odorless, flammable, non-toxic, and non-corrosive. Methane gas is widely used as LNG (Liquid Natural Gas) and CNG (Compress Natural Gas).

Table 1. Pyrolysis Results Data

\begin{tabular}{cccc}
\hline \multicolumn{2}{c}{$\begin{array}{c}\text { Pyrolysis without } \\
\text { Catalyst }\end{array}$} & \multicolumn{2}{c}{$\begin{array}{c}\text { Pyrolysis Add } \\
\text { Catalyst }\end{array}$} \\
\hline $\begin{array}{c}\text { Time } \\
\text { (minute) }\end{array}$ & $\begin{array}{c}\text { Volume } \\
(\mathrm{ml})\end{array}$ & $\begin{array}{c}\text { Time } \\
\text { (minute) }\end{array}$ & $\begin{array}{c}\text { Volume } \\
(\mathrm{ml})\end{array}$ \\
\hline 15 & 300 & 15 & 300 \\
30 & 200 & 30 & 460 \\
45 & 90 & 45 & 230 \\
60 & 40 & 60 & 130 \\
75 & 60 & 75 & 100 \\
90 & 40 & 90 & 60 \\
105 & 20 & 105 & 45 \\
120 & 20 & 120 & 45 \\
135 & 25 & 135 & 40 \\
150 & 25 & 150 & 30 \\
165 & 30 & 165 & 35 \\
180 & 20 & 180 & 35 \\
195 & 25 & 195 & 40 \\
210 & 30 & 210 & 40 \\
225 & 25 & 225 & 40 \\
240 & 25 & 240 & 50 \\
255 & 20 & 255 & 60 \\
270 & 25 & 270 & 60 \\
\hline Total & 1020 & Total & 1800 \\
\hline Pyrolysis & without & catalyst & \\
\hline
\end{tabular}

Pyrolysis without catalyst occurs at a higher temperature with less amount of product gas than pyrolysis added catalyst, which occurs at lower temperature with more amount of product gas produced. The same result was obtained by Govinda et al. [19]. That the higher the temperature, the gas product decreases. However, at a temperature of $550^{\circ} \mathrm{C}$, there is an increase in the amount of gas again. With the increasing number of products in the pyrolysis, the added catalyst is theoretically influenced by a catalyst. The catalyst makes the reactants easier to react because it lowers the activation energy so that it decomposes. It occurs even at lower temperatures.

\section{Determination of Reaction Order}

Observation data for gas formation every 15 minutes interval is made in the form of gas 
formation fraction and then processed based on the integrated rate equation [13].

After that, a plot of the gas fraction (fg) was made against time, and by using the graphical method in MS Excel, a curve and line equation was obtained. This was done to determine the most suitable order of gas formation reaction.

Table 2. Integrated Rate Equation

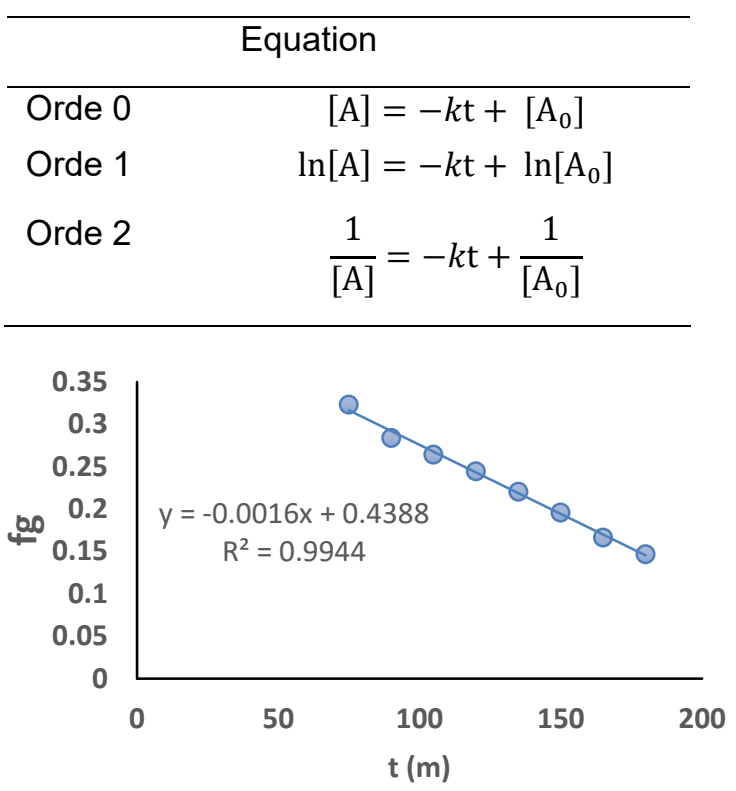

Figure 5. Equation of Lines Without Catalyst Following Zero Order

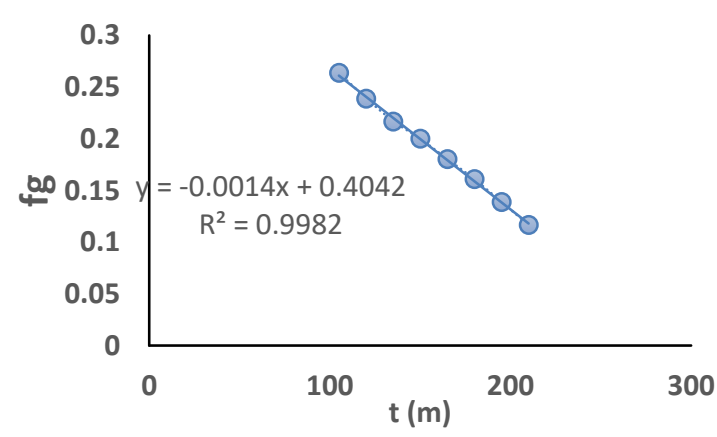

Figure 6. Line Equation with the addition of a Catalyst Following Zero Order

Determination of the most suitable reaction order is to look at the value of R square (R2), which is closest to one [20]. Based on the data obtained from several graphs of line equations, the pyrolysis reaction for gas formation without a catalyst and added catalyst is most appropriate following the reaction order of zero, with an R2 value that is closest to one in Figures 5 and 6 . Theoretically, the reaction order is zero, meaning that the reaction rate does not depend on the change in concentration or volume of the gas when it is formed. According to Laily et al., the value of the reaction order can be used to determine the rate constant of the reaction [21].

\section{Activation Energy}

The gas formation data according to the time of observation of each pyrolysis was processed using the equation of change of reactants to form products [22] to determine the value of the rate constant for each time interval of observation. Where $\mathrm{dml} / \mathrm{dt}$ is the ratio of the change in volume each time interval with the change in time, $\mathrm{ml}$ is the volume for each time interval, $\mathrm{mlO}$ is the initial volume, and mla is the final volume

$$
\frac{d m l}{d t}=\mathrm{K} \cdot f\left(\frac{m l-m l a}{m l 0-m l a}\right)
$$

The value of the rate constant $(K)$ for each time interval obtained from the equation is solved by plotting In $\mathrm{K}$ against $1 / \mathrm{T}$, then using $\mathrm{ms}$ excel the line equations as shown in Figures 7 and 8.

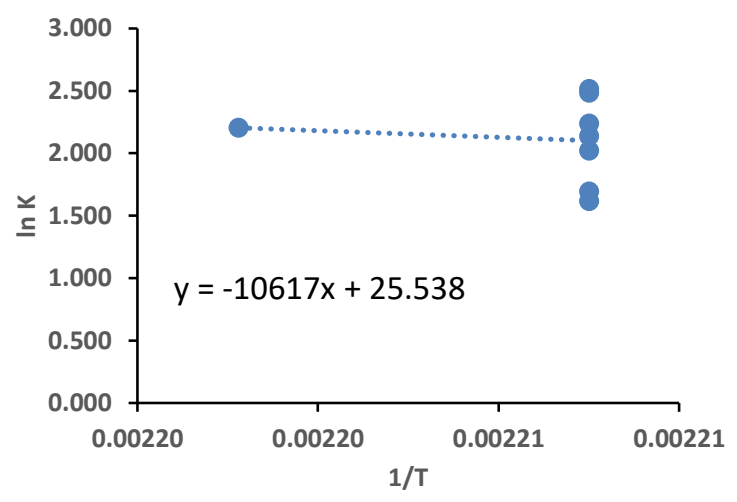

Figure 7. Equation of $\mathrm{Ln} \mathrm{K}$ to $1 / \mathrm{T}$ in Pyrolysis Without Catalyst

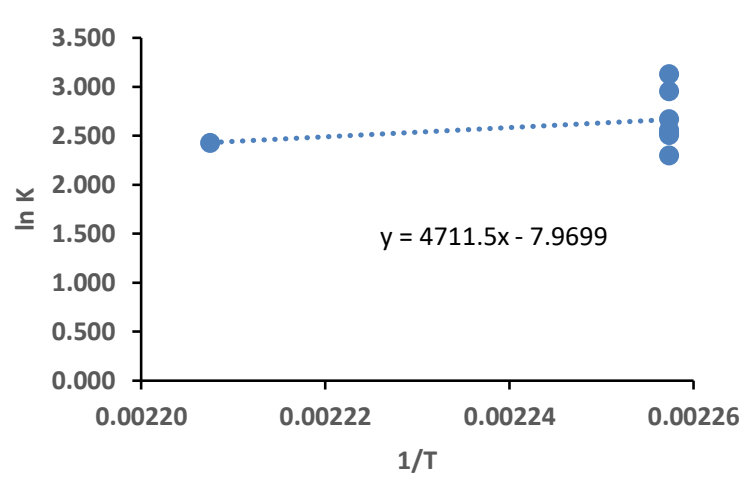

Figure 8. Equation of $\mathrm{Ln} \mathrm{K}$ to $1 / \mathrm{T}$ in Pyrolysis Added Catalyst 
The line equations obtained in Figures 7 and 8 are then entered into the Arrhenius equation in linear form to determine the value of the activation energy (Ea).

$$
\ln k=\left(-\frac{\mathrm{E}_{a}}{\mathrm{R}}\right)\left(\frac{1}{\mathrm{~T}}\right)+\ln A
$$

A straight line equation with a slope of- $E a / R$ is obtained based on the graph of In $\mathrm{K}$ versus $1 / \mathrm{T}$ for each pyrolysis. A straight line equation with a slope of $-E a / R$ is obtained.

Table 3. Activation Energy Value

\begin{tabular}{lccc}
\hline \multicolumn{1}{c}{ Pirolysis } & $\begin{array}{c}\text { Temperat } \\
\text { ure }(\mathrm{K})\end{array}$ & $\begin{array}{c}\text { Slope } \\
-E a / R\end{array}$ & $\mathrm{E}_{\mathrm{a}}(\mathrm{kj} / \mathrm{mol})$ \\
\hline With Catalyst & 453 & 10.617 & $1.277,002$ \\
Without Catalyst & 443 & 4711,5 & 566,694 \\
\hline
\end{tabular}

A reaction can occur if the energy of the collision between the reactants during the reaction exceeds the activation energy [23]. The effect of the catalyst on the activation energy at the time of pyrolysis took place was slightly different because the starting time of observation and the temperature at which the pyrolysis took place was different. This difference is because it is impossible to control the temperature inside the reactor during heating during pyrolysis. But the effect of the catalyst can be observed at temperatures, where the pyrolysis temperature with added catalyst is lower than the pyrolysis temperature without a catalyst.

\section{Arrhenius Equation}

The Arrhenius equation is used to see the relationship between the rate constant and temperature in the pyrolysis of styrofoam. $T$ is the temperature in kelvins, and $R$ is the gas constant which is $8.314 \mathrm{~J} / \mathrm{K}$.mol with $A$ as the collision factor. $\mathrm{K}=A e^{-\mathrm{Ea} / \mathrm{RT}}$

Table 4. Arrhenius Equation of Pyrolysis of Gas

\begin{tabular}{llc}
\hline Pirolisis & $\begin{array}{l}\text { Temperat } \\
\text { ure }(\mathrm{K})\end{array}$ & $\begin{array}{l}\text { Rate Constant } \\
\text { Exponential } \\
\text { Equation.(minute }{ }^{-1} \text { ) }\end{array}$ \\
\hline $\begin{array}{l}\text { With } \\
\text { Catalyst }\end{array}$ & 453 & $\mathrm{~K}=\mathrm{Ae}^{-10617 / \mathrm{RT}}$ \\
$\begin{array}{l}\text { Without } \\
\text { Catalyst }\end{array}$ & 443 & $\mathrm{~K}=\mathrm{Ae}^{-4711,5 / \mathrm{RT}}$ \\
\hline
\end{tabular}

According to Dadang et al. (2019), the higher the heating temperature, the faster the kinetic rate of decomposition of styrofoam [22]. It should have an impact on the amount of product produced.

\section{CONCLUSION}

It is known that the pyrolysis of styrofoam without a catalyst for gas formation at a temperature of $180^{\circ} \mathrm{C}$. Pyrolysis of styrofoam with a zeolite catalyst added to the formation of gas at a temperature of $170^{\circ} \mathrm{C}$ takes place on the zero-order. The kinetics parameters of gas formation in the pyrolysis of styrofoam without a catalyst follow the Arrhenius equation $\mathrm{K}=$ Ae10617/RT. The activation energy value (Ea) is $1.277 \times 103 \mathrm{~kJ} / \mathrm{mol}$, and the Styrofoam pyrolysis with added catalyst follows the Arrhenius equation $\mathrm{K}=\mathrm{Ae} 4711,5 / \mathrm{RT}$ and the energy price activation (Ea) of 5,666 x 102 $\mathrm{kJ} / \mathrm{mol}$.

\section{REFERENCES}

[1] Anom, I.D.K. dan J. Z. Lombok. 2020. Karakterisasi Asap Cair Pirolisis Sampah Kantong Plastik Sebagai Bahan Bakar Bensin. FULLERENE Journal of Chemistry., 5(2), 96-101.

[2] Mahendra A. W., Arijanto. 2017. Pengolahan Sampah Plastik Jenis Pet(Polyethilene Perepthalathe) Menggunakan Metode Pirolisis Menjadi Bahan Bakar Alternatif. Jurnal Teknik Mesin., 5(1), 9-15.

[3] Ruhama D. M., Ratno S., T. Hadi W. A. 2018. Sampah Anorganik Sebagai Ancaman Di kawasan Ekosistem Hutan Manggrove Kuala Langsa. Jurnal Jeumpa., 5(2), 84-90.

[4] Vita W., Natasha E., Evelyn A., Johnner S. 2020. Variasi Jarak Antar Layer Bentonit Pada Pembuatan Nanokomposit PlaBentonit Sebagai Kemasan Makanan. Indo. J. Chem. Res., 8(1), 57-65.

[5] Bemis, R., Jamarun, N., Arief, S. 2012. Pengolahan Limbah Polipropilen Menjadi Bahan Bakar Cair Melalui Metode Pirolisis. J. Ris. Kim., 5(2), 158-164.

[6] Westerhout, R. W. J, Waanders, J., Kuipers, J. A. M., van Swaaij, W. P. M. 1997. Kinetics of the Low Temperature Pyrolysis of Polyethene, Polypropene, and Polystyrene Modeling, Experimental Determination and Comparison with Literature Models and Data. Int. Eng. Chem. Res., 36 (6). 1955-1964.

[7] Marnoto T. dan Endang S. 2012. Tinjauan Kinetika Pyrolysis Limbah Polystiren. Prosiding Seminar Nasional Teknik Kimia Kejuangan., (08), 1-5. 
[8] Zurohaina., Tahdid., Ahmad Z., Yohandri B., Zulkarnain., Desi N. S., Nila W., Putra M. R. A., Agung R. Analisa Bahan Bakar Minyak Hasil Pirolisis Sampah Plastik Jenis PP dan PET Terhadap Kinerja Generator Set pada PLTSA Plastik Kapasitas 1000 Watt. Jurnal Kinetika., 10(1), 24-30.

[9] Wirawan W. Mandala., Cahyono S. M., Ma'arif S., Sukarjo H. B., Wardoyo. Pengaruh Suhu Terhadap Rendemen dan Nilai Kalor Minyak Hasil Pirolisis Sampah Plastik. Jurnal Mekanika dan Sistem Termal., 1(2), 49-52.

[10] Nasrun N., Eddy K., Inggit S. 2016. Studi Awal Produksi Bahan Bakar Dari Proses Pirolisis Kantong Plastik Bekas. Jurnal Teknologi Kimia., 5(1), 30-44.

[11] Ahmed I. O., Charlie F., Alaa H. L., Ahmed S., John H., Davis W. R. 2020. Pyrolysis kinetic modelling of abundant plastic waste (PET) and in-situ emission monitoring. Environmental Sciences Europe., 32 (112), 1-12.

[12] Maafa I. M. 2021. Pyrolysis of Polystyrene Waste: A Review. Polymers., 13(2), 225.

[13] Feybi A. G. Kauwo., I Dewe K. Anom., John Z. Lombok. 2021. Pyrolysis Reaction Kinetics of Styrofoam Plastic Waste. Indo. J. Chem. Res., 9(1), 57-62.

[14] Kumara D. C., Wijayanti W., Widhiyanuriyawan D. 2015. Pengaruh Penggunaan Katalis (Zeolit) Terhadap Kinetic Rate Tar Hasil Pirolisis Serbuk Kayu Mahoni (Switenia Macrophylla). Rekayasa Mesin., 6(1), 19-25.

[15] Syamsiro Mochamad. 2015. Kajian Pengaruh Penggunaan Katalis Terhadap Kualitas Produk Minyak Hasil Pirolisis Sampah Plastik. Jurnal Teknik., 5(1), 4756.

[16] Reno P., Wiwiek D. 2015. Pengaruh Penggunaan Katalis Zeolit alam dalam pirolisis Limbah Plastik Jenis HDPE menjadi Bahan Bakar Cair Setara Bensin. Prosiding Semnastek.

[17] Rosa M., Jin Y., Christian R., Cornelia V. 2001. Vacuum pyrolysis of commingled plastics containing PVC I. Kinetic study. Polymer Degradation and Stability., 72, 469-491.

[18] Naimah S., Aidha N. N. 2017. Karakteristik Gas Hasil Pirolisis Limbah Plastik Polietilena (PE) Dengan Menggunakan Katalis Residue Catalytic Cracking (RCC). Jurnal Kimia dan Kemasan., 39(1), 31-38.

[19] Govinda S. A., Chandra W.P., Hary S.. 2017. Kinetika Reaksi Kimia Pirolisis dari Limbah Plastik Polipropilen dengan
Variasi Efek Penambahan Bentonit Kedalam Katalis Zeolit alam, Tesis, Universitas Gadjah Mada. Yogyakarta.

[20] Mitha P., Sutijan., Arief B. 2016. Kinetika Reaksi Pirolisis Eceng Gondok. EKSERGI., 13(1), 13-16.

[21] Laily N. dan Rustam M. 2019. Studi Kinetika Antibakteri Dari Hasil Pirolisis Cangkang Biji Jambu Mete Terhadap Staphylococcus Aureus. Indo. J. Chem. Res., 6(2), 74-80.

[22] Dadang H., Andy H., Purbo S., Febi R. 2019. Pengaruh Temperatur Pirolisis Terhadap Energi Aktivasi pada Tar Limbah Plastik. Jurnal Flywheel 10(1), 9-17.

[23] Haryono. 2017. Analisa Kinetika Reaksi Pembentukan Kerak CaCO3-CaSO4 dalam Pipa Beraliran Laminar pada Suhu $30^{\circ} \mathrm{C}$ dan $40^{\circ} \mathrm{C}$ Menggunakan Persamaan Arrhenius. TRAKSI., 17(2), 40-51. 